\title{
EU TERMINOLOGY IN INTERPRETER TRAINING: SELECTED PROBLEM AREAS CONNECTED WITH EU-RELATED TEXTS
}

\author{
EWA KOŚCIALKOWSKA-OKOŃSKA \\ Ewa.Koscialkowska-Okonska@umk.pl \\ Nicolaus Copernicus University in Toruń, Poland
}

\begin{abstract}
The presentation refers to the entire area of translating legal terminology, in particular to the translation of EU law-related texts that are especially vital for translating the acquis communautaire. This area of translation (and interpreting) services has been developing rapidly. The language used in documents is specialist and, at the same time, specific, due to the terminology used. Both the translator and the interpreter face the responsibility and the obligation to observe and apply translation strategies, consistently selected and considering the already existing and valid names, terms, concepts, definitions etc., by means of such available sources of information as dictionaries, encyclopedias, lexicons or special glossaries. Problems that translators and interpreters may encounter focus, to a large extent, on (un)translatability of certain terms, ambiguity of EU-speak or textual coherence, or the absence of it, which results from unclear, vague or ambiguous style of the original. On the other hand, the challenge for the translator/interpreter is constant care of the quality of the text created in Polish, which substantially affects the standard level and quality of Polish that we use everyday. Quality is the concept in translation and interpreting closely related with successful performance and communication (with all its aspects). The attempt at quality description in this context, apart from subjective impressions resulting from our understanding of the importance of features that good competent - translation and effective communication should have, cannot be devoid of focusing on three principal factors, i.e., the translator/interpreter (as the text author/ producer), translation/interpreting process and product, which is the result of this process and, finally, involvement (and competence) on the part of the translator/interpreter. All the above aspects pose a real challenge for the translator/interpreter focusing on legal terminology.

Selected aspects of the aforementioned issues shall be verified in a case study conducted on trainee interpreters.
\end{abstract}

Key words: translation, interpreting, quality, legal terms

\section{Introduction}

This article refers to the specific area of translating EU law-related texts that are especially vital for the translation of the entire acquis communautaire. The language used in documents is specialist and, at the same time, specific, due to the terminology used. Both the translator and the interpreter face the responsibility and the obligation to 
observe and apply translation strategies, consistently selected and considering the already existing and valid names, terms, concepts, definitions etc., by means of such available sources of information as dictionaries, encyclopedias, lexicons or special glossaries. Problems that translators and interpreters may encounter focus, to a large extent, on (un)translatability of certain terms, ambiguity of EU-speak or textual coherence, or the absence of it, which results from unclear, vague or ambiguous style of the original. On the other hand, the challenge for the translator/interpreter is constant care of the quality of the text created in Polish, which substantially affects the standard level and quality of Polish that we use everyday. Quality is the concept in translation and interpreting closely related with successful performance and communication (with all its aspects). The attempt at quality description in this context, apart from subjective impressions resulting from our understanding of the importance of features that good competent - translation and effective communication should have, cannot be devoid of focusing on three principal factors, i.e., the translator/interpreter (as the text author/ producer), translation/interpreting process and product, which is the result of this process and, finally, involvement (and competence) on the part of the translator/interpreter. All the above aspects pose a real challenge for the translator/interpreter focusing on legal terminology.

Translating EU-related texts, including normative ones (in the remainder of the article referred to as EU texts) tends to be in a constant state of development. These texts must be translated due to the legal obligation imposed on EU member states that assumes the acknowledgement of the entire legal output and legal regulations of the European Union (i.e., acquis communautaire). The language used in those documents is a specialist language, thus having characteristic features inherent to specialist texts; this language, if we follow Šarčević (2000), is even considered a sub-language subject to certain specific syntactic, semantic and pragmatic rules. Another feature typical of the language of EU texts is specialist vocabulary that aims at precise and accurate description of the reality embraced within the normative functioning of legal documents. In these documents the passive voice is frequently used together with impersonal forms; these are accompanied by nominalisations (nominalising is in general a characteristic feature of legal texts; see Jopek-Bosiacka 2006). The priority of translation, and therefore the priority of the translator and interpreter, is accurate and precise message transfer.

Terminology occurring in legal texts seems to be, to quite a substantial degree, incoherent in terms of concepts (Šarčević, 2000); this is mostly determined by circumstances behind the emergence and evolution of legal systems. Each legal system has its own legal realia, own conceptual systems derived from the operation of institutions in a given state, cultural or historical aspects or, last but not least, socioeconomic factors. In any system there are legal concepts that, due to systemic differences, may not have conceptual or terminological equivalents in other languages as they do not exist (either in a culture or in a given legal system). The translator may find support in glossaries (either printed or on-line) containing binding and relevant terminology applied in legal documents or regulations, EU institutions, EU funds and programmes (e.g. IATE tem-base - Inter-Active Terminology for Europe that has been in existence since 2007 and offers wide access to multilingual terminology in various fields of EU operation). 


\section{Translation-related problems}

In the process of translating EU-related texts most frequently occurring problems include untranslatability (which is an inherent feature of translation in general, but that is too broad a field to discuss considering space limitations of this article) and cultural barriers related with it which shall be briefly described below.

Untranslatability is mostly connected with finding appropriate equivalents for concepts and notions typical of a given country for, inter alia, geographical reasons (for instance, olive growing in Mediterranean countries and specialist vocabulary related with it; cf. Chesterman et al. 2002). Moreover, notions and concepts typical of a given country tend to be quite frequently replaced with more general (or even safer, if we might say so in this context), euro-speak. The very term of 'euro-speak' embraces to a large extent terms and concepts occurring in the aforementioned glossaries or term bases (for the detailed explanation of the term see Chesterman et al. 2002). Even more interesting is the application of 'supranational' terms (cf. Chesterman et al. 2002); this derives from the fact that translating certain concepts by means of one, allegedly 'correct' term applied in a given country might be misleading (even if such an accurate equivalent operates in the target language). The supranational term is better in the sense that it does not produce direct 'national' associations, therefore associations connected with a specific legal regulation or a term to be found in detailed provisions: the text itself is concerned with a supranational term, and not a national equivalent.

The cultural barriers, addressed above, are related with references occurring in EU texts that might be typical of the culture of the language that is the source language of the document (see the concept of 'authentic text' by Aust, 2000). It is difficult to assume identical cultural and historical knowledge of receivers (here an example that we might give concerns the importance of Charlemagne in Western Europe, or the perception of the role of King Casimir the Great with an a priori assumption - quite popular in Poland - that this king is commonly known in Europe and is equally important for the development of Europe as Charlemagne, which, to say the least, is not always the case).

\section{Specific nature of interpreting}

All the abovementioned issues do exert an impact on the performance and quality of interpreting which, in the context that we are focusing on, denotes an interaction of cognitive factors affecting the translation process in general (i.e., memory, knowledge, decision making and problem solving, motivation, experience, creativity or intelligence). Knowledge accumulated by the interpreter throughout his or her professional (and life) experience can be effectively utilised while performing interpreting tasks; this is enabled by activating and retrieving information necessary in a given context. Interpreters should also constantly develop and broaden their knowledge in order to be able to produce a good quality translation: without being motivated they would not be capable to do that (for external and internal motivation see Amabile 1996).

Interpreting - in the almost classical view of Gile (1995) - is a highly complex verbal activity performed under time pressure. It is meaning-oriented, and precise and accurate transfer of that meaning is perceived as priority (this is also well reflected in 
research studies, e.g. Bühler 1986, Kurz 1986, Kurz 1993, Mesa 2000, Pöchhacker 2000, Kadric 2000); the interpreter is the one who controls the rate of information processing. Another factor vital for interpreting is its social context as it is a service provided for different user groups (listeners, clients). Effective performance of translation functions i.e., enabling communication in a given situational context - results from the translator's competence manifested in the process. This competence is a consequence of the interaction of the aforementioned cognitive factors. One of manifestations of competence that facilitates the performance of a translation task but also poses a challenges due to its very nature is quality. This concept, owing to its significance and function performed in interpreting deserves a wider discussion.

\section{The concept of quality}

For interpreting research quality has not always been in the very centre of attention as the scholars began to investigate the issue only somewhat over twenty years ago. As they were working in a sense individually, the results of the research were many individual definitions of quality, rather than one clear and precise definition instead. Maybe this has become an inherent feature of quality research as we perceive it from today's context: it is a multifarious, complex, even slightly vague term, in which varying research concepts and paradigms are, to an extent, intertwined. Attempts as specifying quality per se and its parameters were reflected in empirical studies of such scholars as - in the chronological order - Bühler (1986), Kurz (1989, 1993), Marrone (1993), Kopczyński (1994), Moser (1995), Mesa (2000), Kadric (2000) or Pöchhacker (2000, 2002). The research mentioned introduced a dichotomous distinction between varying perspectives, vital for the quality assessment process and undoubtedly affecting it, into interpreters and interpretation users (listeners or recipients). Different groups of users may have differing perceptions of quality and this subjectivity has been reflected in the research mentioned; yet, despite varying expectations, a number of key pillars for quality description have been distinguished. These are accuracy, clarity, precision and sense consistency with the original message (Pöchhacker seems to corroborate the above by determining accuracy, equivalence, adequacy and communicative success as pillars pivotal for high-quality effective interpreting; see Pöchhacker 2002).

A definition of quality must take into account in this context a triad of factors resulting in successful performance, namely, the interpreting process, the interpreting product and the interpreter him/herself (being the producer/author of the text). The interpreting process embraces various stages such as, for instance, preparing for a specific task, collecting necessary information and doing research. The interpreting product is a manifestation of the quality in the interpreter's performance and results from the functioning and interaction of the already mentioned linguistic, extralinguistic and cognitive factors. The product is assessed in quality-related terms, also with regard to professional codes of ethics or standards that should be complied with by professional interpreters. Obviously, there are substantial differences as to these standards in various countries, or even - in terms of legal translation and interpreting - in various courts, yet some universals seem to be commonly acknowledged. These universal features were nicely summarised by Mikkelson $(2000,2008)$ in the form of four major features of 
professional interpreters, i.e., impartiality, fidelity, professional conduct and confidentiality.

All interpreters should be impartial, regardless of the venue where an interpreting event is held. The assumed neutrality and impartiality of the interpreter should never have any impact on the performance (see Gile 1995 for the term 'rotating-side taking' denoting loyalty shifts). In the legal context, the interpreter controls the communicative situation (with parties to a case being in conflict and distrustful of one another) and is thus obliged to interpret utterances in the most accurate and precise manner possible so as to avoid any doubts whether he/she changes anything in the message that is to be conveyed.

Fidelity assumes the need to transfer the meaning of an utterance in its entirety, thus the interpreter cannot change, omit or add anything. This need is not only derived from professional requirements, but it is mostly of legal nature: the text to be translated into the target language should contain both linguistic and extralinguistic elements that appear in the original. Mikkelson also lists a number of problems that might emerge during interpretation and distort its faithful transfer and which should be reported; these are, for instance, too high tempo of speech, no breaks while interpreting, too long sentences or speech fragments that are a burden to memory.

Professional conduct is related with observing the court and its procedural standards. It also refers to the interpreter being able to cooperate with other interpreters and even to offer assistance, or ask for support, should the need arise. The interpreter, if he/she is professionally honest, is to deal only with tasks for which he/she is appropriately qualified. Preparation for the task, already mentioned above, is adequate if accompanied by doing necessary research and collecting information that might be of help for task performance. This seems to be in close relation with the obligation to be fulfilled by all interpreters, namely, to have a high degree of motivation for constant development and broadening one's knowledge by means of e.g., participating in conferences and meetings to exchange ideas, thoughts and experiences with other professionals in the field and updating their knowledge in the area of their specialisation.

As regards confidentiality, the interpreter is not to reveal or take benefit of the information that he/she obtained while working. Thus, no comments in public should ever be made that refer to issues or cases the interpreters are to deal with.

The above considerations leave us with certain postulates concerning the grounds for successful and high-quality translation and interpreting performance: it is the result of perfect command of both the source and target languages, constantly improved qualifications and broadened knowledge (both general and specialist including the knowledge of textual conventions, of special use in the legal domain) and professional ethical standards.

\section{The norm and creativity}

The very term 'standard' seems to open a new path in our deliberations on successful and quality performance as a 'standard' tends to be interchangeably applied with the notion of 'norm'. The norm in translation in general is a very broad concept, and the 
focus will not be laid on the norm typology (see Toury 1995), but rather on its importance and implications for quality-related performance.

Norms in translation have been perceived from the social and cultural perspective: since translation and interpreting fulfil certain social functions enabling communication, norms may be treated as the transposition of values or ideas common for a given society into appropriate "instructions" of how to behave or proceed. These are to be applied in a situation, in which certain constraints on procedures or behavioural patterns may occur. The emergence and acquisition of norms is a natural consequence of the socialisation process due to the fact that norms can also be utilised as criteria of evaluation of specific social behaviours (provided a given situation or event allows a variety of behaviours; see Schaffner 1998). The concept of norm is indispensable to explain social implications of actions and behaviours, manifested in social institutions or social order, and thus it contributes to the creation of cultural reality. The problem with norms in the context of translation and interpreting consists in their specificity, i.e., social and cultural characteristics and a certain lack of stability (cf. Toury 1995). Norms are specific from the social and cultural point of view and they exist within the frameworks of a given cultural context. Their interference with other norms results from contacts between cultural systems. The already mentioned lack of stability, or in other words a certain fluidity of norms, derives from their very nature as they are subject to temporary changes that can be ascribed to historical or political conditions.

The operation of norms in translation is hard to be observed. What we really see are the products of the translation/interpreting process and results of the norm-governed procedures as manifested by the translator/interpreter. Translation as being an interactive and communication-focused activity cannot function without the feedback from the environment in a given translation or interpreting event. This feedback is also normgoverned and in this very sense translation is the 'embodiment' of a specific form of the production process of the text/utterance. The feedback from the environment reflects the operation of norms that can be used for mutual reactions existing between texts in the source and target languages; therefore, norms determine the adequacy of procedures applied in translation/interpreting.

In interpreting of extreme importance is the interaction of those cognitive factors that directly affect the entire process, namely, knowledge, experience, processes of decision making and problem solving (the efficiency of which depends on the accrued knowledge and experience), memory, motivation or, finally, creativity, as the result of the interaction of the above factors. When we analyse the operation and application of norms in interpreting, it has to be stressed that although Toury in his theoretical considerations addressed both translation and interpreting, the usefulness of norms in interpreting has not been perceived as valid from the very beginning (see Schjoldager 2002). There were claims as to a very limited number of research corpora, and empirical studies based on such a restricted scope render difficulties in analysing the application of general norms (Shlesinger 1989) and, potentially, constitute investigation material for the formulation of hypotheses on the application of norms (in a given language pair in the corpus). Moreover, it should be emphasised that vital obstacles exist - for creating corpus material - of technical, organisational or even legal nature (for instance, while recording interpreters for the purpose of research). Transcripts of utterances recorded may not reveal all the features inherent for a given interpretation; interpreters are also not always 
willing to be recorded (cf. also Shlesinger 1989). There is an entire group of factors that do affect the process and product of interpreting (be it conference or simultaneous) that cannot be subject to analysis due to the absence of necessary instruments (cf. Diriker 1999). In interpreting, and in simultaneous interpreting in particular, the interpreter interprets in real time which further makes it difficult to asses whether the final interpretation product is a result of the norms applied or rather the result of constraints on information processing capacity (this issue is addressed both by Shlesinger 2000 and Schjoldager 2002). Schjoldager (2002) even postulates to introduce a new norm that would be of effect only in interpreting that would determine what could or should be done by the interpreter in a situation when the degree of difficulty of a given task is rising or even it becomes impossible to be performed. The capacity to proceed with the task in this situation is a trait of professional competence manifested through the operation of translation creativity. The very concept of creativity, due to its significance and function performed in interpreting, with the exclusion of other forms of human intellectual activity due to the absence of space, shall be briefly discussed below.

Scholars and researchers tend to define creativity in a variety of ways. Initially, we can assume the reasoning adopted by Boden $(1992,1994)$ or Sternberg (1999) that creativity results in a product that is both valuable and original (or even unconventional). In empirical research (see Kussmaul 1995, Danks 1999, Shreve 1999, EnglundDimitrova 2005) creativity is positioned in a relatively wide spectrum of translation perception as a psychological operation in general: interpreting relies on cognitive factors and therefore on the recognition capacity and the awareness of the existence of potential problems. It should be underlined, however, that creativity per se is much more complex, which leads to problems related with attempts aimed at its more specific definition. If creativity is seen as seeking solutions most optimal from the point of view of the given specific context in which an interpreting task is performed, then the product of this 'search process' should be effective in the realisation of a given interpreting task.

A creative interpreter has a variety of individual features, owing to which (and owing to mutual interactions) creativity can be manifested at all. These features include motivation and involvement in the work performed as well as a conviction of the value of one's own work, willingness and skill of breaking conventions (see the classical view of creativity of Rogers 1976), experience, general and specialist knowledge, and the ability to take risk. Thus creativity is viewed as the ability of making new (novel) ideas or extracting new (novel) meaning out of the already well known and existing concepts. In interpreting the source text is transferred into the target text, which leads to the creation of an entirely new text, close in terms of content to the original, yet in other aspects it is a brand new text; thus the target text is a creative product. The creativity understood as the construction of new texts is the purpose of the translator's activity and the purpose of translation in general perceived as intercultural communication: its aim is to overcome barriers between two language and cultural realities.

On the other hand, keeping balance between creative activity of the interpreter and re-creating the sense of the message in the source language is vital. It necessitates the need to apply translation strategies and procedures as well as to utilise the new resources (e.g., cognitive ones, see Neubert 2000). These strategies (with concurrent application of cognitive factors such as knowledge or experience) interact with the creative potential that is manifested by the interpreter (cf. Gran 1998). Effectively accrued knowledge 
combined with experience, memory, motivation, intelligence or other cognitive factors form grounds for effective operational processes of decision making and problem solving as practiced by interpreters. Yet, creativity manifested by an individual devoid of sufficient degree of experience and knowledge would not be fully realised in an interpreting task. The absence of the awareness of the individual's creative potential or the absence of the skill to assess it appropriately could possibly result in the application of ineffective procedures and strategies and, finally, in the selection of inappropriate or incorrect translation solutions.

\section{The study}

A potentiality of the operation of this mechanism was the objective of a brief study conducted among students of the Post-Graduate Studies in Translation and Interpreting at the Nicolaus Copernicus University in Torun. Prior to discussing the research proceedings and results, a brief elucidation of interpreter training objectives seems to be in order.

While considering interpreter training in general it is essential to bear in mind that trainees should ideally have psychological features indispensable for professionals to make the training process efficient and the trainees confident about skills they develop and improve. These features embrace good memory, ability to manage stress, motivation for constant development, broadening knowledge and gaining experience; they are yet in the process of constant development in trainees.

We might also ponder about yet another aspect in interpreter training, i.e., the role of theoretical insights into the subject matter being the focus of interpreting. This particularly refers in our situation to the knowledge of the law and law-related aspects as manifested in interpreting. It would be feasible to follow Kaiser-Cooke in her saying that the combination of practice and theory in training is "not only compatible, but mutually necessary" (Kaiser-Cooke 2000:68). Therefore, new theories may originate from practical results, or empirical background may be a stimulus for practical implications. Training thus covers such aspects as the awareness of potential strategies of effective problem solving and decision making, and this knowledge may be of use in the process of developing (professional) skills.

Trainees do face a variety of requirements, ranging from extensive general knowledge (to be followed by specialist knowledge in particular areas of specialisation), command of both languages and a number of cognitive factors that we have already mentioned before. Yet, theoretical aspects and expectations concerning their performance form just one side of training, the other being practice (or reality, for that matter). This reality is reflected in the possessed awareness of trainees' skills and competencies. Trainees tend to have expectations as to what their performance should be like; they also seem to recognise areas of potential deficits in either their interpreting performance or cognitive resources (or both of them).

The group under research consisted of 18 persons. In the majority of cases (apart from one person being a law graduate), the students are graduates of the English studies who would like to become professional translators (and interpreters) in the future. The study was performed during classes in consecutive interpreting; the students had had 30 
hours of practical consecutive interpreting exercises before. The material subject to be analysed during the classes constituted the research base: the students had both lexical and content-related knowledge enabling them - at least in theoretical terms - to interpret the text correctly. The text to be interpreted concerned one of the most essential EU funds, namely, the European Social Fund. The students were equipped with a special ESF glossary combined with practical knowledge in translating texts on the ESF functioning in which ESF-related terms occurred. The research consisted in interpreting fragments of the text on the ESF with a special focus being laid on the manner, in which students interpreted specific terms as well as the selection of variants that they used. Selected examples of the interpretation of specific terms are included in the table below (the number of instances where a given term was used is given in brackets; if the number is not given, then a specific term was used only once). In a number of cases no equivalents were offered and students decided not to interpret a term they were not familiar with.

\begin{tabular}{|l|l|}
\hline \multicolumn{1}{|c|}{ ESF term } & \multicolumn{1}{|c|}{ Equivalent variants in Polish } \\
\hline Community Support Framework & $\ldots$. wsparcia społecznego \\
(CSF) & program wspierania społeczności (3) \\
& ramy wspierania społeczności \\
& system wsparcia społeczności \\
& no equivalent (5) \\
& system wsparcia społecznego \\
& plan wspierania wspólnotowego \\
& plan wspierania inicjatyw społecznych \\
& wspólnotowe ramy wsparcia \\
& program wsparcia społeczeństwa \\
& plan działania na rzecz wsparcia rozwoju \\
& społecznego \\
& ramowy plan \\
& program/plan wsparcia społeczności \\
\hline Eligible costs - & $\ldots \ldots$ koszty \\
& no equivalent (5) \\
& koszty uprawnione (2) \\
& koszty uzasadnione \\
& przejrzyste koszty \\
& transparentne koszty \\
& koszta \\
& przewidywane koszty (2) \\
& koszty kwalifikowane \\
& szacowane koszta \\
& koszty faktyczne \\
& koszty rzeczywiste \\
& dostosowane koszty \\
\hline Implementing institution - & instytucja wdrażająca (5) \\
& brak ekwiwalentu (3) \\
& instytucja wprowadzająca w życie \\
& instytucja realizująca \\
& instytucja ds. implementacji \\
& inicjatywa zastępcza \\
& instytucja implementująca \\
\hline & \\
&
\end{tabular}




\begin{tabular}{|c|c|}
\hline ESF term & Equivalent variants in Polish \\
\hline Implementing institution - & $\begin{array}{l}\text { instytucja wprowadzająca } \\
\text { instytucja odpowiedzialna za wdrożenie (3) } \\
\text { instytucja }\end{array}$ \\
\hline Intermediate Body - & $\begin{array}{l}\text { władza pośrednicząca } \\
\text { organ pośredniczący (6) } \\
\text { ciało pośredniczące (3) } \\
\text { ciało pośrednie } \\
\text { organizacja pośrednicząca (2) } \\
\text { no equivalent (3) } \\
\text { instytucja pośrednia } \\
\text { instytucja pośrednicząca } \\
\text { organizacja pośrednia } \\
\text { jednostka pośrednicząca }\end{array}$ \\
\hline Managing Authority - & $\begin{array}{l}\text { Władza } \\
\text { władze nadzorujące (2) } \\
\text { instytucja zarządzająca (2) } \\
\text { władza zarządzająca (4) } \\
\text { ciało zarządzające } \\
\text { organ zarządzający (5) } \\
\text { zarzą } \\
\text { instytucja zarządzająca } \\
\text { no equivalent } \\
\text { dyrektor } \\
\text { szef }\end{array}$ \\
\hline Measure - & $\begin{array}{l}\text { miara (4) } \\
\text { wielkość (2) } \\
\text { środek (7) } \\
\text { pomiar } \\
\text { skala } \\
\text { ocena } \\
\text { wskaźniki } \\
\text { no equivalent (2) } \\
\text { rozmiar }\end{array}$ \\
\hline National Development Plan & $\begin{array}{l}\text { narodowy plan rozwoju (10) } \\
\text { krajowy plan rozwoju (3) } \\
\text { krajowa strategia rozwoju } \\
\text { narodowa strategia rozwoju } \\
\text { plan rozwoju państwa } \\
\text { plan rozwoju kraju } \\
\text { plan rozwoju narodowego } \\
\text { plan rozwoju krajowego }\end{array}$ \\
\hline Payment application - & $\begin{array}{l}\text { aplikacja (2)/ podanie o finansowanie } \\
\text { podanie o dokonanie płatności (2) } \\
\text { wniosek o płatność } \\
\text { formularz/wniosek aplikacyjny o wypłatę środków } \\
\text { no equivalent (2) } \\
\text { wniosek } \\
\text { formularz dopłat } \\
\text { wniosek płatności } \\
\text { generator wniosków płatniczych }\end{array}$ \\
\hline
\end{tabular}




\begin{tabular}{|l|l|}
\hline \multicolumn{1}{|c|}{ ESF term } & \multicolumn{1}{c|}{ Equivalent variants in Polish } \\
\hline Payment application - & druk uiszczenia opłaty \\
& uiszczenie wpłaty \\
& sposób płatności \\
& formularz płatności \\
& płatność \\
& formularz opłat \\
\hline Ultimate beneficiary - & końcowy (4)/ostateczny beneficjent (6) \\
& no equivalent (3) \\
& beneficjent docelowy (2) \\
& beneficjent \\
& efekty końcowe \\
& ostateczny odbiorca \\
& odbiorca końcowy \\
& ostateczne korzyści \\
& końcowe korzyści \\
\hline
\end{tabular}

From the above table one might infer that despite the access to glossaries, vocabulary lists and prior preparation, students while performing consecutive interpreting tend to forget about them or, at any possible costs, they are trying to find and use equivalents created ad hoc. In the follow-up discussion the students, while explaining their translation decisions, claimed the stress factor and time constraints as most significant for their performance; they also said that they did not always recognise and value highly glossaries and binding equivalents. They were also sure that the interpreter should in all situations and at any time be creative since creativity forms the basis of good and effective translation/interpreting performance. They did not, however, consider the fact that creativity existing for its own sake and being realised in a sort of enforced manner does not result in producing a good translation or interpreting; on the contrary, it becomes a burden. Excessive focusing on creativity and its manifestations may lead to problems related with proper message conveyance. Another interesting aspect is the occurrence of breaks in interpreting in places where no equivalents were provided. This might seem a 'strategy', although hardly recommendable: providing no equivalent, or in other words, leaving a term not translated and disintegrating the fluency of delivery tends to be a method of proceeding with the text typical of beginner, inexperienced interpreters, despite the awareness of the inappropriateness of this sort of interpreter behaviour.

\section{Conclusions}

The transfer of messages contained in the original is the priority of translation in general; in particular the terminological precision and accurate conveyance of the sense of the source language message is of fundamental importance in interpreting (including the interpretation of EU-related texts that are normative in nature). Interpreting as synergistic (co)operation of knowledge, memory, experience, processes of decision making and problem solving is undoubtedly a creative operation in the sense of creating a product (an interpreted text) that is novel, original, valuable or the best out of a possible number of variants. It should be borne in mind that creativity in good translation 
and interpreting is most of all the balance between what is novel and original and what is optimal from the point of view of the perception of a given text. The ability to keep this balance is the ability to assess one's own potential as an individual that embraces one's own translation competence that results from cognitive factors and the aforementioned creativity. It can be postulated that the absence of this ability is the reason for so many translation problems; it is also responsible for the results of research conducted among students of the Post-Graduate Studies in Translation and Interpreting at the Nicolaus Copernicus University in Torun. Yet, we may hope that acquiring the ability to assess this potential depends on experience accrued, and thus the would-be interpreters have a wide array of challenges to face in the future.

\section{References}

Amabile, Teresa M., 1996, Creativity in context. Boulder, Co: Westview.

Aust, Anthony, 2000, Modern treaty law and practice. Cambridge: Cambridge University Press.

Boden, Margaret, 1992, The Creative Mind: Myths and Mechanisms. New York: Basic Books

Boden, Margaret, 1994, Dimensions of Creativity. Cambridge: MIT Press.

Bühler, Hildegund, 1986, „Linguistic (semantic) and extra-linguistic (pragmatic) criteria for the evaluation of conference interpretation and interpreters", Multilingua 5, 4: $231-235$.

Bylard-Ozeroff, A., Králová, J. and B.Moser-Mercer, (eds.), 1998, Translators' strategies and creativity, Amsterdam: Philadelphia: John Benjamins.

Danks, Joseph H., Shreve, Gregory M., Fountain, Stephen B., \& McBeath, Michael K. (eds) 1997. Cognitive Processes in Translation and Interpreting. Thousand Oaks, CA: Sage

Diriker, Ebru, 1999, "Problematizing the discourse on interpreting - A quest for norms in simultaneous interpreting", [in:] TexTconTexT 132, 73-90.

Chesterman, A. and E.Wagner (eds.), 2002, Can Theory Help Translators, Manchester: St Jerome Publishing.

Englund Dimitrova, Birgitta, 2005, Expertise and Explicitation in the Translation Process. Amsterdam /Philadelphia: John Benjamins.

Gile, Daniel, 1995, Basic Concepts and Models for Interpreter and Translator Training. Amsterdam: Philadelphia: John Benjamins.

Gran, Laura, 1998, "In-Training Development of Interpreting Strategies and Creativity", [in:], Translators' strategies and creativity, A.Bylard-Ozeroff, J.Králová, J. and B.Moser-Mercer (eds.), Amsterdam: Philadelphia: John Benjamins, 145-162.

Jopek-Bosiacka, Anna, 2006, Przekład prawny i sadowy. Warszawa: PWN.

Kadric, M., K.Kaindl and F.Pöchhacker (eds.), 2000, Translationswissenschaft, Tübingen: Stauffenburg Verlag.

Kaiser-Cooke, Michele "Theory in practice: translation as trans-disciplinary action". In Translationswissenschaft, M. Kadric, K. Kaindl and F. Pöchhacker, (eds.) 67-79. Tubingen: Stauffenburg Verlag. 2000. 
Kopczyński, Andrzej 1994. "Quality in conference interpreting: Some pragmatic problems",[in:] S.Lambert and B.Moser-Mercer (eds.), Bridging the gap. Empirical Research in simultaneous interpretation. Amsterdam: John Benjamins.87-100.

Kurz, I., 1989, "Conference Interpreting: User Expectations", [in:], Coming of Age: Proceedings of the $30^{\text {th }}$ Annual Conference of the American Translators Association, D.L.Hammond (ed.), Medford/New Jersey: Learned Information, 143-148.

Kurz, Ingrid, 1993, „Conference Interpretation: Expectations of different user groups”, The Interpreter's Newsletter, 5, Universita degli Studi di Trieste, SSLM, 13-21.

Marrone, Stefano 1993. "Quality: A Shared Objective", The Interpreter's Newsletter, 5, $35-41$.

Mesa, A.-M., 2000, “The Cultural Interpreter: An Appreciated Professional. Results of a Study on Interpreting Services: Client, Health Care Worker and Interpreter Points of View", [in:] The Critical Link 2: Interpreters in the Community, R.P. Roberts and S.E.Carr (eds.), Amsterdam/Philadelphia: John Benjamins, 67-79.

Mikkelson, Holly, 2000, Introduction to Court Interpreting, Manchester: St Jerome Publishing.

Mikkelson, Holly, 2008, "Evolving views of the court interpreter's role: Between Scylla and Charybdis", [in:] Crossing Borders in Community Interpreting, Carmen ValeroGarces and Anne Martin (eds.), Amsterdam/ Philadelphia: John Benjamins, 81-97.

Moser, Peter 1995. "Simultanes Konferenzdolmetschen. Anforderungen und Erwartungen der Benutzer. Endbericht, im Auftrag von AIIC", Wien: SRZ Stadt- und Regionalforschung.

Neubert, Albrecht, 2000, "Competence in Language, in Languages, and in Translation", [in:], Developing Translation Competence, C. Schäffner and B. Adab (eds.), Amsterdam: John Benjamins, 3-18.

Pöchhacker, Franz and Miriam Schlesinger (eds.). 2002. The Interpreting Studies Reader. London/New York: Routledge

Roberts, R.P. and S.E.Carr (eds.), 2000, The Critical Link 2: Interpreters in the Community. Amsterdam/Philadephia: John Benjamins.

Rogers, Carl R. 1976. "Toward a Theory of Creativity", [in:] Rothenberg and Hausman 1976. Reprinted from ETC. A Review of General Semantics, Vol. 11, No. 4, 1954.296-305.

Šarčević, Susan, 2000, New approach to legal translations. The Hague: Kluwer Law International.

Schjoldager, Anne, 2002, "An exploratory study of translational norms in simultaneous interpreting: methodological reflections", [in:] The Interpreting Studies Reader, F. Pöchhacker and M.Shlesinger (eds.), London: Routledge, 300-311.

Shlesinger, M., 1989 "Extending the theory of translation to interpretation: Norms as a case in Point", [in:] Target 1: 1, 111-15.

Shlesinger, Miriam, 2000, "Interpreting as a Cognitive Process: How can we know what really happens?", [in:] Tapping and mapping the processes of translation and interpreting: outlooks on empirical research, S. Tirkkonen-Condit and R. Jääskeläinen (eds.), Amsterdam: John Benjamins, s. 3-15.

Shreve, G. M. and B. J. Diamond, 1997 "Cognitive Processes in Translation and Interpreting: Critical Issues", [in:] Cognitive Processes in Translation and Interpreting, .J.H. Danks (ed.), Thousand Oaks, London, New Delhi: Sage, 233-251. 
Sternberg, Robert J., 1999, Cognitive Psychology, Fort Worth: Harcourt Brace College Publishers.

Toury, Gideon, 1995, Descriptive Translation Studies and Beyond, Amsterdam/ Philadelphia: John Benjamins Publishing Company. 